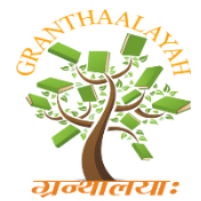

\author{
INTERNATIONAL JOURNAL OF R
GRANTHAALAYAH \\ A knowledge Repository
}

Management

\title{
MANAGEMENT OF SILVOFISHERY PONDS BASED ON PUBLIC KNOWLEDGE AND MOTIVATION IN COASTAL AREA OF PANGKEP REGENCY
}

\author{
Budiman Yunus ${ }^{* 1}$, Dan Basse Siang Parawansa ${ }^{1}$ \\ ${ }^{1}$ Department of Fisheries, Faculty of Marine Science and Fisheries, Hasanuddin University, \\ Indonesia
}

\begin{abstract}
This study aims to analyze the management pattern of integrated mangrove ponds (silvofishery) as a form of creating an environmentally friendly ecosystem and the sustainable use of its resources. The study was conducted through direct observation of three silvofishery patterns that were developed based on the level of knowledge and motivation of the farm-pond community in the coastal area of archipelago Pangkajene District, Pangkep Regency. The research variables consist of 3 integrated management patterns, namely: 1) embankment path pattern, 2) trench path pattern, and 3) complangan pond pattern. These three patterns want to know their contribution to the production of Chanos chanos biomass, Penaeid shrimp, and Scylla sp., as a natural biodiversity and as indicator of environmentally friendly and sustainable ecosystems. Knowledge and motivation data on environmental management (silvofishery) are analyzed based on Structural Equation Modeling (SEM). Whereas the production of 3 silvofishery patterns were analyzed by Anova by SRD (0.05) test. The results showed knowledge and motivation contribute positively to the management of integrated silvofishery patterns. Furthermore, these three patterns of silvofishery contribute positively in maintaining pond production (milkfish, shrimp and crab), where the silvofishery pond pattern gives a greater influence value, and supports the realization of sustainable management of integrated ecosystems of mangroves and ponds.
\end{abstract}

Keywords: Silvofishery Knowledge; Motivation; Mangrove and Pond Ecosystem.

Cite This Article: Budiman Yunus, and Dan Basse Siang Parawansa. (2020). "MANAGEMENT OF SILVOFISHERY PONDS BASED ON PUBLIC KNOWLEDGE AND MOTIVATION IN COASTAL AREA OF PANGKEP REGENCY." International Journal of Research Granthaalayah, 8(3), 49-56. https://doi.org/10.29121/granthaalayah.v8.i3.2020.126.

\section{Introduction}

Human activities in meeting their needs are increasingly developing their orientation towards the exploitation of the environment and its resources. Along with the increase in population, inevitably humans will increasingly undermine environmental assets in the form of production land, 
especially for residential needs, food and housing clothing, as well as various needs for the results of mining, minerals and other household furniture. Likewise, in coastal zones, the need for ponds is growing more extensively, causing widespread scale degradation of mangrove forests which has an increasingly worrisome ecosystem crisis in the coastal environment in the future. Pangkep Regency, South Sulawesi, has 1,764 hectares of mangrove forest and is spread in 2 main districts that are directly related to the coastal zone, namely; Liukang Tupabbiring District and archipelago Pangkajene District with an area of $68 \%$ and $32 \%$ of the total area, respectively. The two districts are suspected to have been over exploited since the last three decades. The natural experience and learning of the pond farmers that has been taking place has been important for the ongoing management of the mangrove intercropping ecosystem model (silvofishery) which is expected to realize the implementation of environmental governance and its resources wisely and sustainably. For this management case, research has been carried out in optimizing the management of mangrove land by developing silvofishery patterns based on community knowledge and motivation on the coast of Pangkajene Kepulauan Regency.

\subsection{Purpose and Objectives}

Starting from the view and background of the need for integrated silvofishery management, it is interesting to do research in the archipelago Pangkajene District area as a basis for case studies that aim to find out how knowledge contribution and the role of farmer-pond motivation in realizing and maintaining integrated ecosystem management patterns (silvofishery) as a form of fisheries development that produces optimal production, environmentally friendly and sustainable.

\section{Research Methods}

\subsection{Time and Location}

The study was conducted for approximately 3 months, namely from mid-March 2018 to the end of June 2018 on the coast of Pangkajene Kepulauan District (including Anrong Appaka, Tekolabbua, and Padoang-Doangan Village) Pangkep Regency (Figure 1).

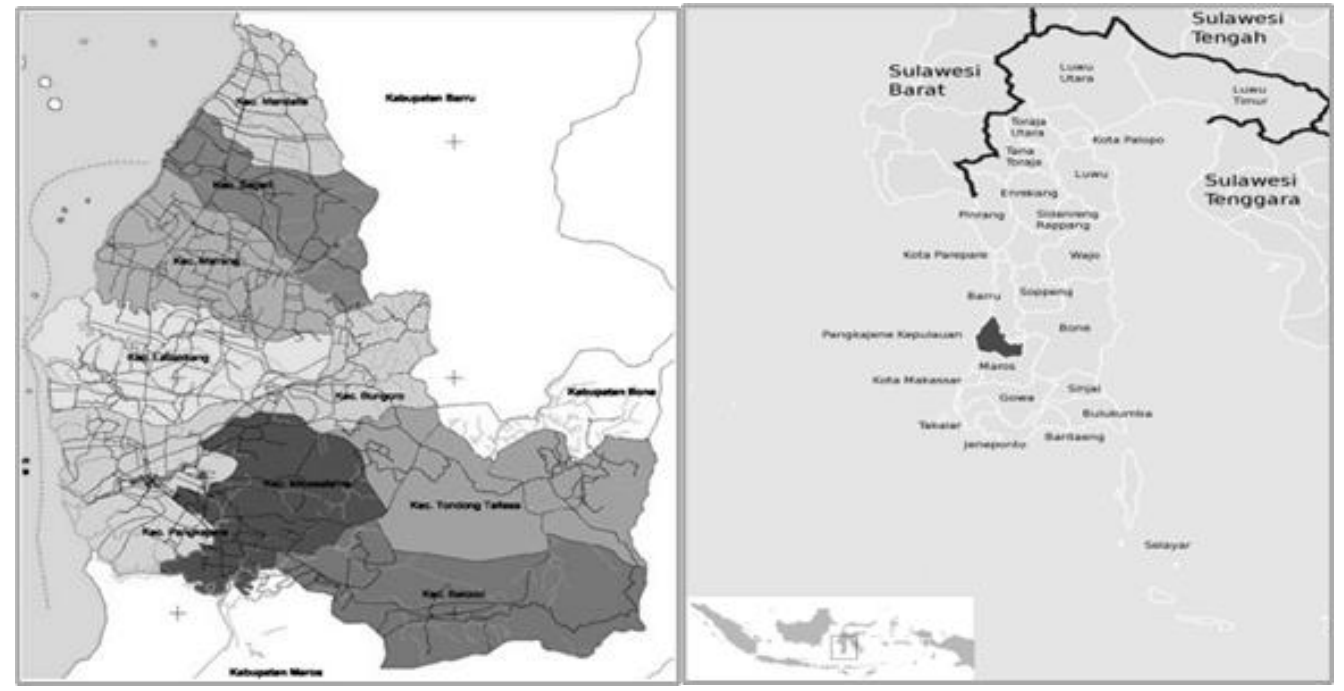

Figure 1: Map of Research Locations in Pangkep Regency 


\subsection{Data Analysis and Procedure}

The approach taken is the introduction of assets and the role of pond farmers which include variables: 1) level of knowledge; 2) motivational drivers which include: a) monthly per capita income; b) experience of KUD organizations and the like; c) ownership rights to ponds; and d) distance of access to the work location. With a Likert scale, the quality of each variable is analyzed its effect on the development behavior of silvofishery activities as a form of structuring an environmentally friendly and sustainable ecosystem.

\subsubsection{Knowledge and Education Level}

The level of knowledge and education of farm farmers is based on the level of natural experience (don't know, don't know enough, know enough, and really know) and levels of education that have been passed from the level of education: never attended school, primary education, secondary education until higher education which is then given a category with a Likert scale of 1-4. The contribution of knowledge and education as well as the motivation of the farming community is analyzed by Structural Equation Modeling (SEM) (Yamin and Kurniawan, 2009).

\subsubsection{Movers of Motivation}

1) Monthly income per capita

Farmers' income is based on income (nominal rupiah per month) obtained from the farm production business activities they manage. This income is categorized on a Likert scale from the lowest to the highest of the income range according to the World Bank 2008 for developing countries which is US \$ 95 - 350, -

2) Organizational experience

The participation of farm farmers in institutions or social organizations (such as KUD and the like) that support their activities is determined based on the experience that has been experienced, i.e. with the category of never, ever, active, and very active that is scaled based on Likert 1-4.

3) Farm ownership rights

There are four types of land ownership status that are generally attached to individual rights in pond land management namely; as cultivators, tenants, users of state land, and owners. This ownership status is also categorized on a Likert scale with each of 1-4.

4) Distance to job location

The distance from the farmer's house to the farm location is suspected to have a meaning in motivating themselves to develop intercropping pond management activities with mangroves (silvofishery). Based on this, this access is also divided based on a Likert scale with 4 (four) categories, namely: very far $(>5 \mathrm{~km})$, relatively far $(5 \mathrm{~km})$, close $(3-4 \mathrm{~km})$, and very close (1-2 km ).

\subsubsection{Silvofishery Management Patterns}

Behavior relating to mangrove land conversion activities can be in the form of farm activity patterns which are selected by the farmer community based on shared knowledge of educational level, as well as motivation towards environmental management (ecosystems) they have (Clough 
et al., 2002). To find out the influence of silvofshery integrated management patterns as environmental behavior consisting of; a) trench patterns, b) embankment patterns, c) komplangan pond patterns, on fish and shrimp biomass production, Complete Randomized Design (CRD) was conducted with Anova test (Sarwono, 2009) and Yasin (2015), with mathematical equations as follows:

$$
\mathrm{Yij}=\mu+\mathrm{Xi}+\varepsilon \mathrm{ij}
$$

Note: $\mathrm{Yij}=$ The results of observing the pattern of management of silvofishery $\mathrm{i}, \mathrm{j}$-replication $\mu=$ Common middle value

$\mathrm{Xi}=$ The influence of $\mathrm{i}$-silvofishery management patterns

$\varepsilon \mathrm{ij}=$ Influence of errors of $\mathrm{i}$-silvofishery management patterns, $\mathrm{j}$-replications

\subsubsection{Production}

The integrated production of ponds in ecological silvofishery management can be seen as mass production of biodiversity in pond aquaculture biota (in the case of this study crab, fish-shrimp). This production is expressed in kilograms of expansion hectares $(\mathrm{kg} / \mathrm{ha})$.

\section{Results and Discussion}

\subsection{Knowledge / Education Contribution}

From 100 pond farmers as respondents spread in three villages (Anrong Appaka, Tekolabbua, and Padoang-Doangan) in the Pangkajene Islands District, proportionately shows the high contribution of the 5 (five) accesses that accompany it (Table 1). Based on Table 1, access to knowledge and secondary education and above means a significant contribution to the sustainable management of integrated ecosystems from the portion of 100 pond farmers in 3 villages throughout the Pangkajene Islands District. The results of the Structural Equation Model (SEM) analysis showed Construct Reability $(\mathrm{R}=0.790)$.

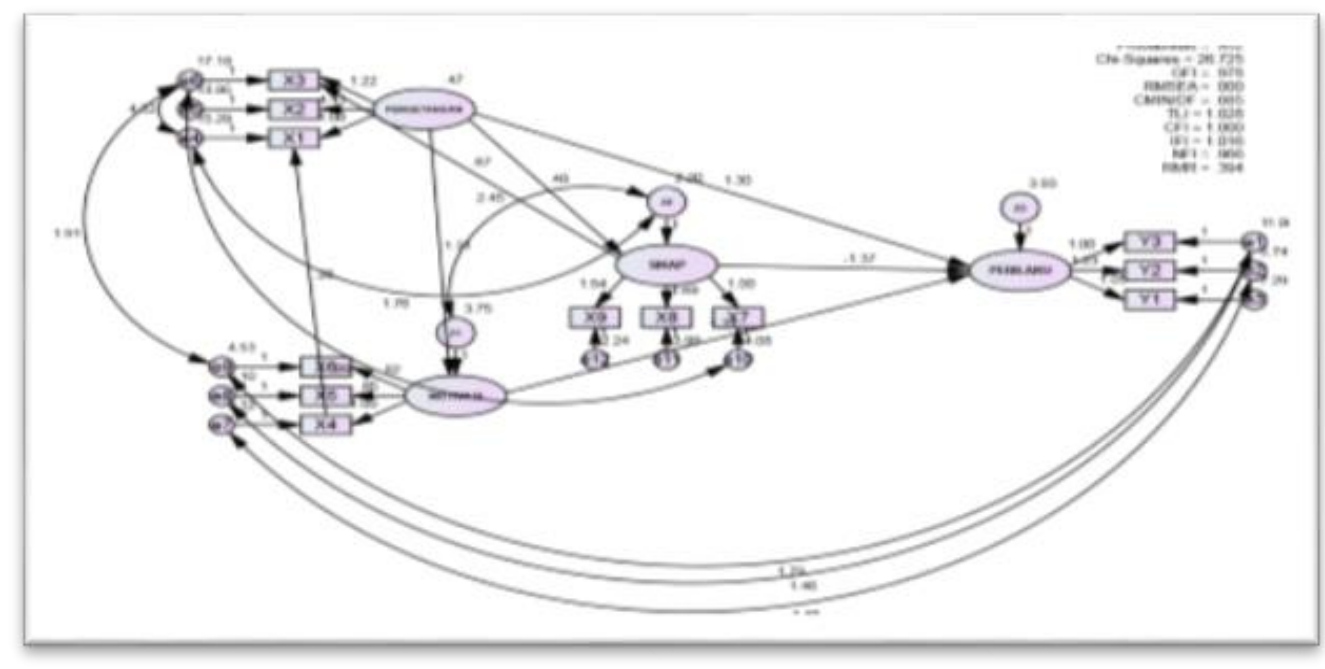

Figure 2: Structural Equation Model (SEM) Results 
Table 1: Test the validity of simultaneously knowledge and motivation variables on silvofishery behavior

\begin{tabular}{|c|c|}
\hline Variable & Validity of CR \\
\hline Environmental Knowledge & 0.790 \\
\hline Activator of Environmental Motivation & 0.932 \\
\hline Silvofishery Insightful Behavior & 0.760 \\
\hline
\end{tabular}

Soerjani (2009) argues that with adequate knowledge and education, a person's character can develop positively influencing attitudes and behaviors in interacting with the natural surroundings. Yunus (2015) also stated that the indicator of ecosystem knowledge refers to one's understanding of the relationship of mutual interactions between ecosystem components, both the living (humans, plants, animals or other organisms) as biotic factors, as well as inanimate objects (soil, water, air and other material content) as abiotic factors, as well as to understand how reciprocal interactions work as a system of natural order.

Table 2: Quality of access to farmer ponds based on Likert scale in the management of silvofishery ponds on the coast of Pangkep district

\begin{tabular}{|c|c|c|c|c|c|c|c|c|}
\hline \multirow[t]{2}{*}{$\begin{array}{l}\text { Sub-district/ } \\
\text { village }\end{array}$} & \multirow{2}{*}{$\begin{array}{c}\text { Number of } \\
\text { Farmers- } \\
\text { Ponds } \\
\text { (Indiv.) }\end{array}$} & \multirow[t]{2}{*}{$\begin{array}{c}\text { Proportional } \\
(\%)\end{array}$} & \multicolumn{5}{|c|}{$\begin{array}{c}\text { Quality of Category } \\
\text { Silvofishery Pond Farmers' } \\
\text { Access }\end{array}$} & \multirow[t]{2}{*}{ Average } \\
\hline & & & 1 & 2 & 3 & 4 & 5 & \\
\hline $\begin{array}{c}\text { Pangkep } \\
\text { Anrong Appaka }\end{array}$ & 32 & 32 & $3 / 3$ & 3 & 4 & 3 & 3 & 3,2 \\
\hline Tekolabbua & 47 & 47 & $3 / 3$ & 2 & 4 & 3 & 3 & 3 \\
\hline $\begin{array}{l}\text { Padoang- } \\
\text { Doangan }\end{array}$ & 21 & 21 & $3 / 3$ & 3 & 3 & 4 & 3 & 3,2 \\
\hline Total & 100 & 100 & 3 & 2,5 & 3,5 & 3 & 3 & 3 \\
\hline
\end{tabular}

Note: 1-5: Access variables (Knowledge, and motivational drivers)

\subsection{Contribution of Motivation}

The approach of accessing motivation based on four motivational variables shows a construct of high validity discriminant $(\mathrm{R}=0.932)$ (Table 1$)$. Conceptually, work motivation is one of the determinants of one's work performance whose effectiveness on performance depends on how much intensity the motivation is given (Uno, 2012).

1) Income

With an average / moderate per capita income (Rp. 2,500,000 - Rp. 3,500,000) / month, it means being motivated in developing sustainable integrated ecosystem management. Bambang (2004) states that with sufficient and continuous income can lead to a more developed motivation and creativity of someone to find solutions to financing problems, especially related to environmental interactions with production effectiveness.

2) Organizational experience

Consistent active participation in organizations, especially Village Unit Cooperatives and other Social Organizations, also contributes positively to the integrated management of 
silvofishery ecosystems. Collaboration with the Village Unit Cooperative and other nongovernmental organizations is a form of farmer participation to encourage more enthusiasm in developing their fishery activities. A person's emotional closeness to financial institutions makes the work spirit in question more aggressively develop their business (Clough at al., 2002). Most of the 100 respondents (64\%) represent the whole community who are active as members of cooperatives and involved in other non-governmental organizations related to environmental management.

3) Farm ownership rights

With the status of land use rights of the state and private property rights with an average of categories 2-4 shows a higher motivation for fish farmers in the archipelago Pangkajene sub-district. With the use rights permit from the government on state land, farmers feel ownership and are enthusiastic in making optimal use of it as effectively as possible by developing calls for sustainable management of silvofishery ponds.

4) Distance to job location

The short distance to very close access from the house of residence to the work location in each research location shows a relatively equal positive contribution from the farmer farmers to the development and management of integrated ecosystems of mangroves and ponds, although there is no apparent difference in contribution to the development activities between the close categories and far from their respective homes.

\subsection{Contribution of Silvofishery Behavior to Production}

Biodiversity of mass production (Chanos-Chanos, Penaeus sp. And Scylla serrata) is shown in Table 3. Based on the research station, the application of silvofishery patterns in the pond farming community in Padoang-Doangan Village, Pangkajene Kepulauan District gave a higher productive contribution (585 kg / ha) of biomass production (fish-shrimp-crab) compared to other villages (Anrong Appaka and Tekolabbua). This shows the positive contribution of knowledge / education variables and motivation drivers, both directly and indirectly to the production of biomass silvofishery management patterns $(\mathrm{R}=0.760)$ (Table 1$)$. Behavioral conception as a manifestation of the abstraction of knowledge, education, and motivation, as well as attitudes that are consistently high in realizing appropriate and concrete (concrete) behavioral patterns (Taylor, at al 2009). Silvofishery-oriented behavior is consistency and self-actualization as a reflection of character as a result of experience, education, knowledge, attitudes and motivation towards integrated management of fish and mangrove cultivation in a pond unit (Yunus, 2015).

Table 3: Biomass production from silvofishery ponds in 3 Villages throughout archipelago Pangkajene District

\begin{tabular}{|c|c|c|c|c|}
\hline \multicolumn{2}{|c|}{ Silvofishery Management Pattern } & \multirow{2}{*}{$\begin{array}{c}\text { Production } \\
\text { (Absolute } \\
\text { Weight: Kg/ha) }\end{array}$} & \multirow{2}{*}{$\begin{array}{l}\text { Average } \\
\text { (Kg/Ha) }\end{array}$} & \multirow{2}{*}{$\begin{array}{c}\operatorname{SRD}_{(0,05)}= \\
1,53\end{array}$} \\
\hline $\begin{array}{l}\text { Village } \\
\text { (Station) }\end{array}$ & $\begin{array}{c}\text { Integrated Silvofishery } \\
\text { Pattern }\end{array}$ & & & \\
\hline Anrong & Emb. & 460,365 & \multirow{3}{*}{454} & \multirow{3}{*}{$\mathrm{a}$} \\
\hline Appaka & Ditch & 393,870 & & \\
\hline & Pond & 507,437 & & \\
\hline \multirow[t]{2}{*}{ Tekolabbua } & Emb. & 625,982 & & \\
\hline & Ditch & 515,245 & $516^{*}$ & $\mathrm{~b}$ \\
\hline
\end{tabular}




\begin{tabular}{|c|c|c|c|c|}
\hline & Pond & 408,215 & & \\
\hline Padoang- & Emb. & 549,750 & & \\
Doangan & Ditch & 455,585 & $585^{* *}$ & $\mathrm{c}$ \\
& Pond & 750,110 & & \\
\hline
\end{tabular}

Table 4: Biodiversity in production (mass weight) Based on integrated pond patterns (silvofishery) in the District of Archipelago Pangkajene

$\left.\begin{array}{|c|c|c|c|}\hline \begin{array}{c}\text { Silvofishery } \\ \text { Management Pattern }\end{array} & \begin{array}{c}\text { Production } \\ \text { (Absolute Weight: Kg/ha) }\end{array} & \begin{array}{c}\text { Average } \\ \text { (Kg /Ha) }\end{array} & \begin{array}{c}\text { SRD }_{(\mathbf{0 , 0 5})=} \\ \mathbf{1 , 5 3}\end{array} \\ \hline \text { Dike pattern } & \begin{array}{r}460,365 \\ 625,982 \\ 549,750\end{array}\end{array}\right\}$

Anova dan SRD $(0,05)$

Biodiversity is an environmental parameter that shows the varied values of flora and fauna life as indicators of ecosystem viability. In this case, biodiversity of production shows the biodiversity of a community-managed ecosystem that depends on conventionally managed mangrove ecosystem management patterns, or through "silvofishery" aquaculture patterns (Yunus, 2015).

\section{Conclusion}

Proportionally, farmers play an active role in realizing the development of integrated ecosystems of mangroves and ponds along the coast of Pangkep Regency, especially in the District of Pangkajene Islands. The development and management of integrated ecosystems (silvofishery) is very closely related to the contribution of knowledge and education level of pond farmers, and is supported by motivational drivers which include income levels, active participation in organizations (Village Unit Cooperatives) as well as other non-governmental organizations, land / land ownership rights, and access to the location of management activities from residential homes.

\section{References}

[1] Bambang, A. N. 2004. Analisa Konsumsi Ikan dalam Hubungannya dengan Tingkat Pendapatan di Kecamatan Pakualaman Yogyakarta. Seminar Nasional dan Hasil-Hasil Penelitian. Fakultas Perikanan dan Ilmu Kelautan (FPK) UNDIP Semarang

[2] Choong E T, Wirakusumah, R S. Ahmad s s. 1990. Mangrove Forest in Indonesia. Forest Ecology and Management. 33/34 : 45 - 47. 
[3] Clough, B., D. Johnston, T.T. Xuan, M.J. Phillips, S.S. Pednekar, N.H. thien, T.H. Dan and P.L Thong. 2002. Silvofishery Farming Systems in Ca Mau Province, Vietnam. Report prepared under the World Bank, NACA, WWF and FAO Consortium Program on Shrimp Farming and the Environment. Work in Progress for Public Discussion. Published by the Consortium.

[4] Lewis, R.R. 1999. Key Concept In Successful Ecological Restoration of Mangrove Forests. TCE - Project Newsletter, 3.(11) : 6-18.

[5] Soerjani, M. 2009. Pendidikan Lingkungan (Environmental Education). Sebagai Dasar Sikap dan Perilaku Bagi Kelangsungan Kehidupan Menuju Pembangunan Berkelanjutan. Institut Pendidikan dan Pengembangan Lingkungan (The Institute for Environmental Education and Development, IEED). Ed. I/2009 IPPL, Jakarta.

[6] Uno, H.B. 2012. Teori Motivasi dan Pengukurannya. Analisis di Bidang Pendidikan. Ed. 1/9 P.T. Bumi Aksara, Jakarta.

[7] Waryono, T. 2007. Keanekaragaman Hayati dan Konservasi Ekosistem Mangrove. Diskusi Panel Program Studi Biologi Konservasi, Jurusan Geografi FMIPA-UI, Depok 2007.

[8] Yamin, S., dan H. Kurniawan. 2009. Structural Equation Modeling. Belajar Lebih Mudah Teknik Analisis Data Kuesioner dengan Lisrel-PLS. Buku Aplikasi Statistik Seri 2. Salemba Infotek, Jagakarsa-Jakarta

[9] Yunus, B. 2015. Perilaku Petani Tambak Berwawasan“Silvofishery” Di Pesisir Pantai Kabupaten Sinjai. Disertasi, Sekolah Pascasarjana - Universitas Negeri Makassar.

\footnotetext{
*Corresponding author.

E-mail address: bu_yun@ymail.com
} 